\title{
Veteriner Hekimlikte Papillomaviruslar ve Önemi
}

\section{Selvi Deniz DÖRTTAŞ ${ }^{1 a}$, Seval BíLGE DAĞALP1b®}

1. Ankara Üniversitesi, Veteriner Fakültesi, Viroloji Anabilim Dalı, Ankara, TÜRKiYE. ORCID: 0000-0001-9543-0211 ${ }^{\mathrm{a}}$, 0000-0002-1166-721X

\begin{tabular}{lc}
\hline $\begin{array}{c}\text { Geliş Tarihi/Received } \\
26.11 .2019\end{array}$ & $\begin{array}{c}\text { Kabul Tarihi/Accepted } \\
10.03 .2020\end{array}$ \\
\hline $\begin{array}{l}\text { Bu makaleye atıfta bulunmak için/To cite this article: } \\
\text { Dörttaş SD, Bilge Dağalp S: Veteriner Hekimlikte Papillomaviruslar ve Önemi. Atatürk Üniversitesi Vet. Bil. Derg.,15(1): 91- } \\
\text { 99, 2020. DOı: } 10.17094 / a t a u n i v b d .651002\end{array}$ \\
\hline Öz: Papillomaviridae, insanlar dahil tüm omurgalıları enfekte edebilen, enfeksiyöz ajanlara bağlı olan kanser vakalarının \% 27- \\
30'undan sorumlu olduğu bilinen en geniş virus ailesidir. Son yıllarda, evcil ve vahşi hayvanlarda çok çeşitli lezyonlara neden \\
olan papillomaviruslar, günümüzde giderek artan sayılarda tespit edilmektedir. Köpeklerde, kedilerde ve sığırlarda oluşan \\
papillomlar veterinerlik alanında önemli bir problemi temsil etmektedir. Papillomaviruslar son yıllarda, büyük çoğunluğu \\
insanlarda ve özellikle sığır, kedi, köpek ve at gibi diğer memeli hayvanlar olmak üzere kuşlar, kaplumbağalar, balıklar gibi \\
memeli olmayan hayvanlarda ve vahşi hayvanlarda artan sayılarda tespit edilmektedir. Özellikle sığır, köpek, at, kemirgen ve \\
insan papillomavirusları hastalıkların tanı, tedavi ve aşı değerlendirmesi için moleküler biyoloji ve hücre biyolojisi üzerine bir \\
model olarak kullanılmakta ve araştırılmaktadır. Yapılan bu araştırmalarla papillomavirus evrimini, biyolojisini, türler arası \\
etkileşimlerini anlama bakımından önemli gelişmeler kaydedilmiştir. Ayrıca çok çeşitli lezyonlara neden olan papillomaviruslar \\
hayvan sağlığı üzerinde büyük etkiler yapabilmekte ve özellikle çiftlik hayvanlarında görülen papillomavirus kaynaklı \\
hastalıklar önemli ölçüde ekonomik kayıplara neden olmaktadır. Bu derlemede, hayvan papillomavirusları hakkındaki son \\
gelişmeleri genel kapsamlarıyla bir araya getirmek ve hızla gelişen bu alanla ilgili bir güncelleme yapmak hedeflenmiştir.
\end{tabular}

Anahtar Kelimeler: At, Kedi, Köpek, Papillomaviruslar, Sığır.

\section{Papillomaviruses and Their Importance in Veterinary Medicine}

Abstract: Papillomaviridae is the largest family of viruses known to be responsible for $27-30 \%$ of cancer cases due to infectious agents that can infect all vertebrates, including humans. In recent years, papillomaviruses, which cause a wide variety of lesions in domestic and wild animals, are now increasingly identified and papillomas in dogs, cats and cattle represent an important problem in veterinary medicine. In recent years, papillomaviruses have been detected in increasing numbers in humans and in non-mammals such as birds, turtles, fish, and other wild animals, particularly other mammals such as cattle, cats, dogs and horses. In particular, cattle, dogs, horses, rodents and human papillomaviruses are used as a model on molecular biology and cell biology for the diagnosis, treatment and vaccine evaluation of diseases. With these studies, important developments have been made in terms of understanding the evolution, biology and inter-species interactions of papillomavirus. In addition, papillomaviruses, which cause a wide variety of lesions, can have great effects on animal health, and especially papillomavirus-related diseases in farm animals cause significant economic losses. This study aims to bring together the latest developments in animal papillomaviruses with their general scope and make an update on this rapidly developing field.

Keywords: Bovine, Cat, Dog, Horse, Papillomaviruses. 


\section{Giriş}

P

apillomaviruslar (PV) bilinen en eski ve en geniş virus ailelerinden biri olarak kabul edilmektedir.

Filogenetik çalışmalar, virusun Afrika'dan köken aldığını ve birden fazla evrimsel kuvvetin etkisinde kalmasının yanı sıra, memelilerin çeşitlenmesiyle konaklarıyla birlikte gelişim gösterdiğini ortaya koymuştur (1). Papillomavirusların oluşturduğu siğil benzeri oluşumların tanınması ilk olarak eski Yunan ve Romalılar zamanına dayanmaktadır. 1900'lerin başında lezyonlardan elde edilen filtratların hastalığı bulaştırdığının gösterilmesiyle, insan siğillerinin viral yapısı tanımlanmıştır. Hayvanlarda ise ilk papillomavirus, 1930'larda yabani pamuk kuyruklu tavşanlarda kutanöz papillomların bulaşıcı niteliğini ortaya koyan Richard Shope tarafından keşfedilmiştir (2). Son yıllarda ise gelişen teknoloji ve yapılan çalışmalarla insan PV'larının yanı sıra hayvan PV'larında da bir artış görülen Papillomaviridae ailesi ICTV raporlarında da belirtildiği gibi iki alt aileden (Firstpapillomavirinae ve Secondpapillomavirinae) oluşmaktadır ve toplamda 53 generada sınıflandırılmakta ve 130 'dan fazla papillomavirus türü içermektedir (3).

\section{PAPILLOMAVIRUSLARIN TAKSONOMISI}

Papillomaviruslar ilk olarak Polyomaviruslar ile beraber Papovaviridae adı altında sınıflandııımıştır. Ancak ortak bir genetik organizasyon sergilemelerine rağmen, papillomavirus genomlarının sekansı polyomaviruslar ile yüksek bir homoloji göstermemektedir ve papillomaviruslar, 2000 yılında ICTV tarafından Papillomaviridae adında farklı bir aile olarak tanımlanmıştır (2). Papillomaviruslar küçük, zarfsız, sirküler, çift iplikçikli DNA (dsDNA) içeren viruslardır. Bu viruslar 6,953bp-8,607bp arası bir genoma sahiptir ve bu küçük boyutlarına rağmen karmaşık bir biyoloji gösterirler (1,4-6). Papillomavirus genomları temelde erken (E), geç (L) ve uzun kodon bölgesi (LCR) olarak 3 bölgeye ayrılır. Erken genomik segment $(E)$, olgunlaşmanın erken aşamalarında epitel hücrelerinde eksprese edilen sekiz ORF içerir. E gen bölgesi E1, E2, E4 replikasyon proteinlerini ve E5, E6, E7 onkoproteinlerini kodlar. Son yıllarda keşfedilen E3 ve E8 in de aynı bölgede olduğu düşünülmektedir (1,7-9). L1 proteini, viral ikozahedral kapsidin ana bileşenidir ve otomatik olarak virion birleştirme yeteneğine sahiptir. Viral enfeksiyon mekanizmasında, hücre zarı içerisinde bulunan heparan sülfat reseptörlerine kapsidin bağlanmasını etkileyen merkezi bir role sahiptir. Geç protein olan L1, en belirgin olarak epitel tabakalarında ifade edilir. Bu nedenle L1' in tespiti, prodüktif enfeksiyonun temel kanıtı olarak düşünülür. $P V$ partiküllerinin birleşimi sırasında L2 ise viral DNA'ya bağlanır ve kapsitlenmeye ve ardından virus salınmasına katkıda bulunur. E1, E2, L1, L2 gen bölgeleri tek başlarına progeny virusun salınmasına yol açan replikasyon, düzenleme, dengeleme ve paketleme gibi temel görevleri teorik olarak yerine getirebilir. Üçüncü bir yapısal protein olan fakat fonksiyonu henüz belirsiz olan L3 ise sadece BPV-4'te mevcut olarak tanımlanmıştır (1). PV'lar enfekte olmuş memeli bireylerde etkili bir humoral bağışık yanıtı uyarmamakta ve bu nedenle serolojiye dayalı bir taksonomi geliştirilememektedir. Uygun bir hücre kültürü ve laboratuvar hayvanı gibi konak sistemlerinin eksikliği de bir sınırlama getirmektedir. Bu sınırlamalara rağmen, PV taksonomisi için temel şartların sağlanmasında DNA dizisi karşılaştırmaları, filogenetik ağaçların topolojisi, bu virus ailesinin taksonomik değerlendirmesinde vazgeçilmez bir kriter olmaktadır (4,5). 2010 yılından bu yana PV sınıflandırması filogeni, genom organizasyonu, biyolojisi ve patojenitesi göz önüne alınarak yapılmaktadır. PV karşılaştırmaları yapmak için ölçüt olarak L1 gen bölgesi seçilmiştir ve bu genin nükleotid seviyesindeki benzerliklerin yüzdelerine göre taksonomik kategoriler belirlenmektedir (6). L1 geninde \%90'dan fazla nükleotid kimliğini paylaşan iki PV genomu aynı PV tipine aittir. Yeni bir PV izolatının filogenetik sınıflandırması yapııırken, L1 bölgesindeki DNA dizisinde mevcut papillomaviruslardan \%10'dan 
fazla farklılık taşıyorsa yeni bir papillomavirus olarak tanımlanmaktadır. \%2-10 arasındaki farklılık alt tip ve $\% 2$ 'den az farklılık gösteriyorsa varyant olarak adlandırılmaktadır (Tablo 1 ).

Tablo 1. Taksonomik Düzey Kriterleri (4).

Table 1. Taxonomic Level Criteria (4).

\begin{tabular}{lc}
\hline Taksonomik Düzey & L1 Orf Benzerliği \\
\hline Genera & $<\% 60$ \\
Tür & $\% 60-70$ \\
Tip & $\% 71-89$ \\
Subtip & $\% 90-98$ \\
Varyant & $>\% 98$ \\
\hline
\end{tabular}

\section{HAYVANLARDA PAPILLOMAVIRUSLAR}

Son yıllarda hayvanlarda papillomavirusların tanımlanmasında büyük bir artış meydana gelmiştir. Farklı evcil ve yabani hayvanlarda tespit edilen papillomaviruslar taksonomide yerini almaktadır. Özellikle bilinen papillomavirusların büyük çoğunluğu insan, sığır, koyun, keçi, kedi, köpek gibi memeli konaklardan izole edilmiştir (10).

\subsection{Bovine Papillomaviruslar (BPV)}

Bovine papillomaviruslar kendiliğinden gerileyen iyi huylu tümörlerin varlığıyla ya da ilerleme gösteren malign neoplazmlarla karakterizedir. Bugüne kadar 5 genusa (cins) ve bir sınıflandırılmamış genusa ayrılmıştır. Deltapapillomavirus genusuna ait Deltapapillomavirus 4 türü BPV-1, $-2,-13$, ve -14 tiplerini; Epsilonpapillomavirus genusu Epsilonpapillomavirus 1 türü altında BPV-5 ve -8 tiplerini; Dyoxipapillomavirus genusu Dyoxipapillomavirus 1 türü BPV-7 tipini kapsar. BPV-16, -18, -22 tipleri Dyokappapapillomavirus genusunda sınıflandırılmıştır. BPV-19 ve -21 tipleri ise henüz sınıflandırılmamış sığır papilloma tipleridir. Xipapillomavirus genusunda ise Xipapillomavirus 1 (BPV-3, -4, -6, -9, -10, -11, -15 ve -23) ve Xipapillomavirus 2 (BPV-12) olmak üzere iki tür bulunur ve bu genusda yer alan BPV -17 ve -20 tiplerinin henüz tür bazında sınıflandırılması yapılmamıştır (1). Son zamanlarda yapılan bir çalışmayla ise BPV-24 olarak adlandırılan bir tip bildirilmiş ve Xipapillomavirus genusuna ait olduğu önerilmiştir (11). Ülkemizde sığır papillomları üzerine yapılan çalışmalarda BPV-1'in yaygın olduğu (12-14), bunun yanı sıra son yıllarda yapılan çalışmalarda ise farklı papilloma vakalarında saptanan BPV türleri arasında dikkate değer bir çeşitlilik olduğu ortaya konmuştur (15). Dağalp ve ark. (16) süt ineklerinin memebaşı papillomatozisinde sınıflandırılmamış yeni tiplerin ve daha önceden tanımlanmış 8 BPV tipin (BPV-1, 2, 3, 4, 6, 7, 9, 10) varlığını örneklenen sürülerde göstermişlerdir.

\subsubsection{Bulaşma ve Çevresel Faktörler}

Bovine papillomavirus kontamine sağım ve bakım ekipmanları, enfekte sığırlarla temas ile kontamine diğer maddeleri de içeren fomitler gibi yollarla saçılır. Yapılan çalışmalarda virus, epitel dokuda ve viral enfeksiyon rezervuarları olarak düşünülen kanda saptanmıştır. Bunun yanı sıra lenfositler, süt, idrar, oosit, yumurtalık, uterus, kümülüs hücreleri ve uterus lavajıyla bulaşabileceği gösterilmiştir. Bunların yanı sıra enfeksiyonun sineklerle bulaşabildiği de düşünülmektedir (17). Yakın zamanda vertikal bulaşma da bildirilmiştir. BPV DNA'sı sığır uterusunda, amniotik sıvıda, plasentada ve yavrulardan toplanan kan örneklerinde tespit edilmiştir. BPV-1 -2 ve -13'ün, özellikle eğreltiotları bakımından zengin topraklarda otlayan sığırlarda mesane karsinojenleriyle ilişkili olduğu ortaya konmuştur. Eğreltiotunun, puquiloside ve quercetin gibi immünosupresan, mutajenik ve kanserojen etkilere sahip toksik bileşenler içerdiği bilinmektedir (18). Eğreltiotunun bu özellikleri BPV persistansını kolaylaştırabilir (19).

\subsubsection{Patogenez ve Patoloji}

PV enfeksiyonları, epitelyum hücrelerinin spinöz katmanında hiperplaziye neden olur. Bunun sonucunda dejenerasyon ve hiperkeratinizasyon gibi değişiklikler görülür. Bu değişiklikler genellikle maruziyetten 4-6 hafta sonra başlar ve gerileme göstermeden önce 1-6 ay süreyle devam eder. Papilloma gelişimi birkaç evrede görülmektedir. 1. 
evrede papillomlar, dermisin fibroplazisi ve bu fibroma ile bağlantılı olarak epitel çoğalması ile başlayarak biraz yükselmiş plaklar şeklinde görülür. 2 . evrede fibropapillomlar virus kaynaklı sitopatoloji, keratinizasyon epitelinde virus replikasyonu ve virion toplanması ile karakterizedir. Bu aşamada, çoğalan epidermis invaziv olarak fibromaya kadar uzanır. 3. evrede ise fibropapillomlar, fibrotik, pedunkülleşmiş yüzeyle ve loblu veya fungiform yüzeylerle karakterize olarak görülür (7).

\subsubsection{Klinik Semptomlar}

Sığır papillomavirusu, epitelyal proliferatif lezyonlara sebep olan ve yaygın olarak görülen sığır papillomatozisi adı verilen bulaşıcı bir hastalığa sebep olmaktadır. Oluşan lezyonlar, çevresel faktör etkisi ile kombine edildiğinde kendiliğinden gerileyebilir veya malignitelere ilerleyebilir. Etkilenen hayvanlar genellikle geç gelişme, kilo kaybı, sütte ve deri kalitesinde azalma gösterir (20). Laktasyondaki ineklerin meme ve meme uçlarını etkileyen papilloma, buzağı besleme ve elle/mekanik sağımda güçlüğe sebep olurken, sekonder bakteriyel enfeksiyonlar ile mastitise yatkınlığı arttırır. Damızlık sürülerdeki enfeksiyonlarda penisin papillomatozisi, hayvanların kesimini gerektirir (21). Kıllı deri, dil, meme ucu, penis ve vulvada gelişen mukokutanöz papilloma ile ağız boşluğunda, özofagusta ve rumende gelişen üst sindirim sistemi papillomalarına neden olur (Şekil 1).

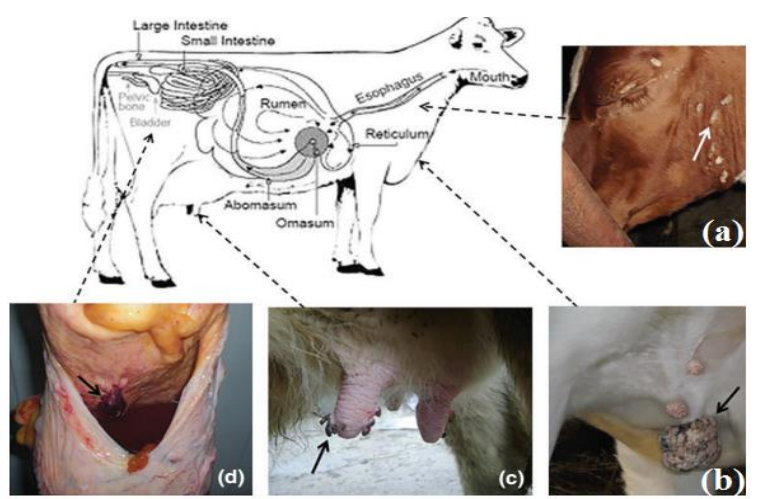

Şekil 1. Sığırlarda bovine papillomavirusların indüklediği lezyonların farklı lokalizasyonu. (a) özofageal papilloma (beyaz ok); (b) kutanöz fibropapillomlar (siyah ok); (c) çok sayıda pirinç şekilli papillomalar (siyah ok); ve (d) idrar kesesi tümörleri (siyah ok) (17).

Figure 1. Different localization of bovine papillomavirus-induced lesions in cattle. (a) esophageal papilloma (white arrow); (b) cutaneous fibropapillomas (black arrow); (c) a plurality of brassshaped papillomas (black arrow); and (d) bladder tumors (black arrow) (17).

Mukokutanöz papillomlar genç hayvanlarda daha sık görülmekte ve çoğu sığırda hayatı boyunca siğiller gelişmeye devam etmektedir. Sığır mukokutanöz papillomalarında skuamoz papillomlar ve fibropapillomlar bulunur. Skuamoz papillomlar insan papillomaları ile aynı histolojik görünüşe sahiptir. Fibropapillomlar ise genellikle BPV-1 ve BPV2 'den kaynaklanır. Hücreler dolgun ve düzenli bir görünümden yoksunlardır. Sığır mukokutanöz papillomların büyük çoğunluğu kendiliğinden geriler (22). Kutanöz papillomlar ise proliferatif benign tümörlerdir. Bu neoplaziler genelde fiziksel olarak hasar görmüş vaskülarize bölgelerde ortaya çıkar. Morfolojik olarak tipik, saplı, atipik, filamentöz ve pirinç benzeri şekilde sınıflandırılmaktadır (1). Üst sindirim sistemi papillomlarında ise hastalık oranları, eğreltiotuna maruz kalma durumuna bağlanmıştır ve eğreltiotu olan coğrafik bölgelerdeki sığırların \% 20'sinde papillom görüldüğü ve bu bitkinin olmadığı bölgelerde sığırların ise sadece \%4.4'ünde papillom olduğu bildirilmiştir. Papillomlar kaudal ağız boşluğundan rumene kadar ilerleyebilir. Üst sindirim sistemi papillomaları genellikle klinik hastalığa neden olmaz ve çoğu bir yıl sonra spontan olarak ortadan kalkar (22).

\subsubsection{Model Olarak BPV'lerin Önemi}

BPV'ler dizilenen ilk papillomavirus genomudur. BPV'lerin patolojisi ve biyolojisi üzerine yapılan çalışmaların sonuçları, HPV'nin de biyolojisi ve patolojisi hakkında fikir vermesi açısından önemlidir. BPV'nin model olarak kullanımı, birden fazla türe yönelik aşıların etkinliğini değerlendirmede ve BPV ile ilişkili kanserin moleküler ve hücresel 
mekanizmalarını belirlemede, persiste ve inatçı lezyonların iyileştirilmesi için immünoterapötik yaklaşımları test etmekte önem arz etmektedir (2327).

\subsubsection{Türler Arası Enfeksiyonlar}

Papillomaviruslar kural olarak tür spesifik kabul edilseler de istisnalar bulunmaktadır; Deltapapillomavirus genusuna ait olan BPV-1, $-2,-5$ ve -13 spesifik bariyerleri aşarak mandaları, atları, tapirleri, zürafaları, eşekleri, bizonları ve zebraları enfekte edebilmektedir. Bu BPV tipleri sığırların yakın akrabalarında fibropapilloma ve idrar kesesi lezyonlarına sebep olabildiği gibi, hayvanat bahçelerinde veya vahşi doğada yaşayan uzak ilişkili türleri de enfekte ettiğinde sarkoidlere sebep olabilmektedir. BPV-8'in de bir varyantının bizonlarda papillomlara neden olduğu gösterilmiştir $(17,20)$. Etkilenen türler arasında, karnivorların filogenetik olarak uzak bir üyesi olan kediler de bulunmaktadır. BPV-14'ün enfekte ettiği evcil kedilerde de sarkoidlere benzer lezyonlar bildirilmektedir $(18,19)$.

\subsection{Equine Papillomaviruslar (EcPV)}

Bugüne kadar sekiz equine papillomavirus tespit edilmiş ve genom sekansları yapılmıştır; Bu viruslar Zetapapillomavirus genusunda yer alan EcPV1, Dyoiotapapillomavirus genusunda yer alan EcPV2, -4, -5 ve Dyorhopapillomavirusu genusunda yer alan EcPV3, -6, -7 ve son zamanlarda Treiskappapapillomavirus genusu olarak EcPV8 olarak sayılmaktadır. Söz konusu viruslar klinik olarak klasik papillomatozise (EcPV1), genital papillomalara (EcPV2) ve kulak papillomlarına (EcPV3-6) sebep olur. EcPV7 ise penisten alınan bir sürüntüde gözlenmiştir. Son zamanlarda yeni bir papillomavirus olarak bulunan EcPV8 ise plak tipi, jeneralize papillom ile ilişkilendirilmektedir $(28,29)$. EcPV-1'in neden olduğu viral papillomatoz tipik olarak 3 yaşın altındaki atları etkiler. Bulaşma, enfekte bir at ile doğrudan temas yoluyla veya dolaylı olarak fomitler yoluyla gerçekleşebilir. Etkilenen bölgeler çoğunlukla baş, dudaklar, göz kapakları ve bacaklardır. Klasik papillomatozis tipik olarak 4-9 ay arası kendiliğinden iyileşme göstermektedir. Atların büyük çoğunluğu virusa karşı tamamen bağışıklık geliştirir ve tekrar enfekte olmazlar. Atlardaki genital papillomaların EcPV-2 ve EcPV-7 ile ilişkili olduğu gösterilmiştir. Bugüne kadar dört papillomavirus (EcPV-3, EcPV-4, EcPV-5 ve EcPV-6), kulak plaklarından alınan örneklerde çoğaltılmış ve filogenetik analizleri Dyoiotapapillomavirus (EcPV-4 ve EcPV-5) ve Dyorhopapillomavirus (EcPV-3 ve EcPV-6) olarak yapılmıştır. Ayrıca EcPV8'in de genital papillomlar dışında kulak plaklarında da bulunabileceği bildirilmiştir $(28,29)$. Kanat ve ark. (30) genital lezyonlu, klinik olarak sağlıklı ve deri tümörü bulunan atlarda yaptıkları çalışmada, deri tümörü olgularında BPV-1 ve EcPV-2 tespiti yapmışlar; ayrıca hem sağlıklı hem de genital lezyonlu atlardan alınan genital swap örneklerinde EcPV-2, BPV-1 ve BPV-2 tiplerini tespit etmişlerdir.

\subsubsection{Equine Sarkoidler}

Birden fazla organda granülomatöz inflamasyon ile karakterize, dışarı doğru üreyen dermatit olarak veya nodüler bir deri rahatsızlığı olarak görülen sarkoidler atları, katırları ve eşekleri etkileyen benign fibroblastik tümörlerdir. Papillomaviridae ailesinin BPV-1 ve -2 tipleri sarkoidlerin patogenezinde önemli faktörler olarak bildirilmiştir. Bazı çalışmalarda, at sarkoidlerindeki BPV-1 L2 proteinde bir delesyon olduğu gösterilmiştir. Bu bulgu, virusun BPV-1 ile tamamen aynı olmadığını önermektedir. Ayrıca sığırlarda BPV enfeksiyonu gerileyebilecek iyi huylu lezyonlar üretirken, sarkoidler virus üretimine izin vermeyen non-permisif ve geri dönüşümsüzdür (31).

\subsection{Feline Papillomaviruslar (FcaPV)}

Kedileri enfekte eden Felis catus Papillomaviruslar (FcaPV), bugüne kadar Lambdapapillomavirus genusunda yer alan FcaPV-1, Dyotheapapillomavirus genusunda yer alan FcaPV-2 ve yapılan çalışmalar sayesinde birbirleriyle ve Taupapillomavirus genusuyla yakından ilişkisi saptanan FcaPV-3, $-4, \quad-5$ türleri olarak 
sınıflandırılmıştır (32,33). FcaPV-1 kedilerde oral papilloma neden olur. Papillomlar dilin ventral yüzeyinde küçük ekzofitik kitleler kümesi olarak bulunurlar. Bu lezyonların büyük bir kısmı hastalığın klinik belirtilerine neden olmadan spontan olarak gerilemektedir (34,35). Dyothetapapillomavirus üyesi olan FcaPV-2 ise preneoplastik cilt lezyonlarının, viral plakların ve bowenoid in situ karsinomaların (BiSK'ler) başlıca nedeni olarak düşünülmektedir (32,36). Bunların dışında kedilerden izole edilen FcaPV-3, aynı zamanda FcaPV-2'den daha az sıklıkta olsa da BiSK'lerde tespit edilmiştir. FcaPV4 ise, ilk defa bir kedinin ağız ve çevresinde tesadüfi bir bulgu olarak bulunmuştur (36). FcaPV-5'in ise atipik viral plaklarla ve BisK'lerle ilişkisi bildirilmiştir (32).

\subsubsection{Feline Sarkoidler}

Kedilerde enfeksiyona sebep olan FcaPV türleri dışında, sığırlarda enfeksiyona sebep olan BPV-14 de çapraz enfeksiyon göstererek kedi sarkoidlerine sebep olmaktadır. BPV-14, at sarkoidlerine de neden olan BPV'lerle yakından ilişkili bir Deltapapillomavirusdur ve kedilerde non-prodüktif bir enfeksiyona neden olabildiği gösterilmiştir. Sığırdan kediye geçiş mekanizması halen bilinmemekle birlikte, lezyonların dağılımı sinekler yoluyla veya kedilerdeki yaralarının BPV-14 ile enfekte edilmesi ile olabileceği düşünülmektedir. Genellikle burun ve üst dudaklar üzerinde gelişirler $(34,35)$.

\subsection{Canine Papillomaviruslar (CPV)}

Günümüzde yirmi Canine Papillomavirus (CPV) tipi önerilmiştir ve bu tipler Lambdapapillomavirus (tip -1 ve -6), Taupapillomavirus (tip -2, -7, -13, -17, 19) ve Chipapillomavirus $(-3,-4,-5,-8,-9,-10,-11$, $12,-14,-15,-16,-18$ ve -20$)$ generalarına ayrılmıştır $(19,35,37)$.

Köpekler CPV'ye bağlı olarak ekzofitik veya endofitik yapıya sahip klasik siğiller, pigmentli plaklar, hiperkeratotik lezyonlar ve bazı durumlarda in situ ya da invaziv squamoz hücre karsinomları (SCC) olmak üzere çeşitli cilt bozuklukları gösterebilir. Özellikle genç köpekler ağız kavitesinde geniş bir yelpazede görülen köpek papillomatozisinden etkilenirler (37). Canine papilomatozis virusu çevre koşullarına karşı çok dirençlidir ve dezenfektanlar ile elimine edilmesi oldukça zordur. Papilomatozis geçirmiş köpekler doğal bir bağışıklık kazanırlar (38). Köpeklerde pigmentli plaklar, genellikle Chipapillomavirus türleri ile ilişkilidir (39). Plaklar genellikle koyu renklidir ve çoklu olarak bulunurlar. Ekstremitelerin ventrum ve medial yönleri üzerinde yaygın olarak görülür. Pigmente plaklarda viral replikasyon ve PV ile indüklenen hücre değişiklikleri gözlenebilir. Pigmentli plaklar, kendiliğinden gerileyebilir, persiste olabilir veya ilerleme gösterebilir. Genel olarak, pigmentli plakların kozmetik önemi olduğu, sağlık üzerinde olumsuz bir etkisi olmadığı düşünülür. Bununla birlikte, pigmentli plakların nadiren malign transformasyonlara uğrayarak invaziv SCC'ye sebep oldukları bildirilmiştir. Malign transformasyon sadece CPV-9, 12 ve 16 ile ilişkili plaklarda bildirilmiş olsa da, yayınlanmış vakalardan bazılarında, diğer PV türlerinin neden olduğu plaklar için malign potansiyelin bulunduğu bildirilmektedir (40). Canine kutanöz papillomlar CPV-1, 2, 6 ve 7 ile ilişkilendirilmiştir. Genç köpeklerde CPV-1'den kaynaklanan oral papillomlar sık görülür. Köpekler CPV-1 tarafından enfekte olduğunda genellikle bu enfeksiyon gözle görülmeyebilir. Köpek oral papillomlarının büyük çoğunluğu kendiliğinden gerilediği için cerrahi eksizyona nadiren ihtiyaç duyulmaktadır. Bu durum, hücre aracılı bir bağışıklık tepkisinin gelişmesinden kaynaklanmaktadır. Deneysel olarak gelişen papillomlarda, iyileşme tipik olarak 8 hafta içinde oluşur. Bağışıklık yetmezliği olan çok sayıda köpekte CPV-2 kaynaklı papillomaların SCC'lere ilerlediği vakalar görülmüştür (35). Son zamanlarda, iki Basenji köpeğinden gelen ve metastatik SCC'ye ilerleyen viral plaklarda CPV12 ve CPV16 tespit edilmiştir. 


\section{PAPILLOMAVIRUSLARDA TANI}

Lezyonlar deride rahatlıkla görülebildiğinden papillomatozisinin tanısı zor değildir. Virusun elektron mikroskopisi ile tanımlanmasında derinin stratum corneum, stratum spinosum ve stratum granülosumundaki hücrelerin çekirdeğinde viral parçacıkların varlığı ortaya konmaktadır. Virusun tespitinde diğer önemli teknik polimeraz zincir reaksiyonudur (PCR). Son yıllarda L1, L2, E6 ve E7 proteinlerini kodlayan genom bölgelerine dayalı olarak tasarlanan FAP59/FAP64 ve MY09/MY11 konsensüs primerleriyle yapılan çok sayıda çalışma vardır. Başlangıçta, insan papillomavirusunda L1 kodlayan genom bölgesi temel alınarak tasarlanan konsensüs primerleri insanlar, sığır ve diğer hayvanlardaki papillomavirusları tanımlamak için sıkça kullanılmaktadır $(1,3,4,35,37,41)$.

\section{PAPILLOMAVIRUSLARDA TEDAVI, KORUMA ve KONTROL}

PV hastalıklarının tedavisinin değerlendirilmesi ve önlenmesi zordur; çünkü hastalık kendi kendini sınırlandırır ve süresi değişkendir. Büyük sürülerde veya lezyon insidansının yüksek olduğu hayvanlarda papillomaların cerrahi eksizyonu yapılabilmektedir. Etkilenen bir hayvanda tümör kitlesinin tamamen çıkarılması, genel fibropapillom regresyonunu uyarabilir ve diğer türlerdeki papillomlar için de aynı durum geçerlidir. Etkilenen hayvanları tedavi etmek için interferon-alfa ve fotodinamik terapi kullanılmıştır. Ancak yaygın olarak kullanımı yoktur. Bunun dışında lazer tedavisi, kriyoterapi, sistemik retinoidler, azitromisin tedavileri, otolog veya rekombinant papillomavirus aşıları ve homeopatik tarantula zehiri tedavisi anekdot olarak bildirilmiştir. Ayrıca ektoparazitlerin biyolojik olarak kontrolünün yapılmasının BPV insidansını azalttı̆̆ı gösterilmiştir. Sınırlı bir etkinliğe sahip olan otojen aşılama gibi aşılama modelleriyle ilgili çalışmalar da bulunmaktadır. Fakat birkaç aşı modelinin önerisine rağmen bugüne kadar BPV'ye ve diğer papillomaviruslara karşı ticari bir aşı formülasyonu geliştirilmemiştir. Dahası, bu aşı modellerinin mutajenik potansiyeli ve stabilitesi hakkında bilgi eksikliği vardır $(1,7,20,26,28)$. Siğil ekstraktlarının profilaktik bir aşı olarak kullanılmasının, köpeklerde oral papillomatozun önlenmesinde etkili olduğu gösterilmiştir (37).

\section{SONUÇ}

Papillomaviridae, insanlar dâhil tüm omurgalıları enfekte edebilen, enfeksiyöz ajanlara bağlı olan kanser vakalarının \% 27-30'undan sorumlu olduğu bilinen en geniş virus ailesidir. Son yıllarda, evcil ve vahşi hayvanlarda çok çeşitli lezyonlara neden olan papillomaviruslar, günümüzde giderek artan sayılarda tespit edilmektedir. Köpeklerde, kedilerde ve sığırlarda oluşan papillomlar veterinerlik alanında önemli bir problemi temsil etmektedir. Papillomavirus kaynaklı lezyonlar özellikle çiftlik hayvanlarında sebep olduğu bazı hastalıklar sebebiyle önemli ölçüde ekonomik kayıplara neden olmaktadır. Yeni viral türlerin keşfedilmesiyle, özellikle sığır ve karnivor papillomavirusların hayvan sağlığı için dünya çapında önemi artmaktadır. Papillomaviruslarla ilgili yapılan yeni keşifler kanser mekanizmasının anlaşımasına katkıda bulunmaktadır. Hayvan papillomavirusları, moleküler ve hücre biyolojisi eğitiminde de önemli modeller olarak görülmektedir. Hayvan yetiştiriciliği ve veteriner tıbbı için gösterdikleri bu önemlere ek olarak, genel papillomavirus kaynaklı lezyonların patogenezinin incelenmesi ve viral enfeksiyonlar ile bunların sonuçlarını ele alan yenilikçi biyoteknolojik araçların geliştirilmesi için de önemli modellerdir.

\section{Çıkar Çatışması}

Yazarlar, çıkar çatışması olmadığını beyan eder.

\section{KAYNAKLAR}

1. Araldi RP., Assaf SMR., Carvalho RF., Carvalho MACR., Souza JM., Magnelli RF., Modolo DG., Roperto FP., Stocco RC., Beçak W., 2017. Papillomaviruses: a systematic review. Genet Mol Biol, 40, 1-21.

2. Knipe DN., Howley PM., 2013. Fields' Virology 
Sixth Edition Lippincott Williams \& Wilkins, Philadelphia, PA, USA.,

3. Van Doorslaer KV., Chen Z., Bernard HU., Chan PK., DeSalle R., Dillner J., Forslund O., Haga T., McBridge AA., Villa LL., Burk RD., 2018. ICTV virus taxonomy profile: Papil-lomaviridae. J GenVirol, 99, 989-990.

4. De Villiers EM., Fauquet C., Broker TR., Bernard HU., Zur Hausen H., 2004. Classifica-tion of papillomaviruses. Virology, 324, 17-27.

5. ICTV (International Committe Taxonomy of Viruses)., 2011. Reports-Papillomaviridae.

6. Bravo IG., Felez-Sanchez M., 2015. Papillomaviruses viral evolution, cancer and evolutionary medicine. Evol Med Public Heal, 28, 32-51.

7. Dubovi E. J., Maclachlan J.N., (2017). Papillomaviridae and Polyomaviridae. Fenner's Veterinary Virology, Academic press, Chapter 11. 229-243.

8. Zheng ZM., Baker CC., 2006. Papillomavirus genome structure, expression, and posttranscriptional regulation. Front Biosci, 11, 2286-302.

9. Lunardi M., Alcindo A., Alejandro R., Fernandes A., 2013. Bovine Papillomaviruses-Taxonomy and Genetic Features. In: Current Issues in Molecular Virology-Viral Genetics and Biotechnological Applications. InTech

10. Van Doorslaer K., Ruoppolo V., Schmidt A., Lescroel A., Jongsomjit D., Elrod M., Krab-erger S., Stainton D., Dugger KM., Ballard G., Ainley DG., Varsani A., 2017. Unique genome organization of non-mammalian papillomaviruses provides insights into the evolution of viral early proteins. Virus Evol, 3, 112.

11. Daudt C., da Silva FR., Cibulski SP., Streck AF., Laurie RE., Munday JS., 2019. Bovine papillomavirus 24: a novel member of the genus Xipapillomavirus detected in the Amazon region. Arch Virol, 164, 637-641.

12. Tan MT., Yıldırım Y., Sozmen M., Bilge Dağalp S.,
Yilmaz V., Kirmizigül AH., Gokce E., 2012. A histopathological, Immunohistochemical and molecular study of cutaneous bovine papillomatosis. Kafkas Univ Vet Fak Derg, 18, 739-744.

13. Timurkan MO., Alcigir ME., 2017. Phylogenetic analysis of a partial L1 gene from bovine papillomavirus type 1 isolated from naturally occurring papilloma cases in the northwestern region of Turkey. Onderstepoort J Vet, 84, 1-6.

14. Oğuzoğlu TÇ., Koç BT., Akkutay-Yoldar Z., Salar S., Baştan A., 2019. Detection and whole genomic characterization of Bovine Papillomavirus type 1 associated with severe mammary cutaneous warts in Turkey. Vet Mexico, 6(3) 1-11.

15. Ataseven VS., Kanat Ö., Ergün Y., 2016. Molecular identification of bovine papillomaviruses in dairy and beef cattle: first description of $\mathrm{Xi}$ - and Epsilonpapillomavirus in Turkey. Turkısh J Vet Anim Sci, 40, 757-763.

16. Bilge Dagalp S., Dogan F., Farzanı TA., Salar S., Bastan A., 2017. The genetic diversity of bovine papillomaviruses (BPV) from different papillomatosis cases in dairy cows in Turkey. Arch Virol, 162, 1507-1518.

17. Bocaneti F., Altamura G., Corteggio A., Velescu E., Roperto F., Borzacchiello G., 2016. Bovine papillomavirus: new insights into an old disease. Transbound Emerg Dis, 63, 14-23.

18. Roperto S., Munday JS., Corrado F., Goria M., Roperto F., 2016. Detection of bovine papillomavirus type 14 DNA sequences in urinary bladder tumors in cattle. Vet Microbiol, 190, 1-4.

19. Gil da Costa RM., Peleteiro MC., Pires MA., Dimaio D., 2017. An Update on Canine, Feline and Bovine Papillomaviruses. Transbound Emerg Dis, 64, 1371-1379.

20. Modolo DG., Araldi RP., Mazzuchelli-de-Souza J., Pereira A., Pimenta DC., Zanphorlin LM., Beçak W., Menossi M., Stocco RC., Franco R., Carvalho RF., 2017. Integrated analysis of 
recombinant BPV-1 L1 protein for the production of a bovine papillomavi-rus VLP vaccine. Vaccine, 35, 1590-1593.

21. Campo MS., 2002. Animal models of papillomavirus pathogenesis. Virus Res, 89, 249-261.

22. Munday JS., 2014. Bovine and Human Papillomaviruses. Vet Pathol, 51, 1063-1075.

23. Jeremiah OT., Fagbohun OA., Babalo OJ., 2016. Molecular detection of bovine papilloma viruses associated with cutaneous warts in some breeds ofnigerian cattle. Int J Biotechnol Biochem, 12, 123-130.

24. Forslund O., Antonsson A., Nordin P., Stenquist BO., Hansson BG., 1999. A broad range of human papillomavirus types detected with a general PCR method suitable for analysis of cutaneous tumours and normal skin. J Gen Virol, 80, 2437-2443.

25. Ogawa T., Tomita Y., Okada M., Shinozaki K., Kubonoya H., Kaiho I., Shirasawa H., 2004. Broad-spectrum detection of papillomaviruses in bovine teat papillomas and healthy teat skin. J GenVirol, 85, 2191-2197.

26. Christensen ND., Budgeon LR., Cladel NM., Hu J., 2017. Recent advances in preclinical model systems for papillomaviruses. Virus Res, 231, 108-118.

27. Gil da Costa RM., Medeiros R., 2014. Bovine papillomavirus: Opening new trends for comparative pathology. Arch Virol, 159, 191198.

28. Linder KE., Bizikova P., Luff J., Zhou D., Yuan H., Breuhaus B., Nelson E., Mackay R., 2018. Generalized papillomatosis in three horses associated with a novel equine papil-lomavirus (Ec PV 8). Vet Dermatol, 29, 72-e30.

29. Torres SMF., Koch SN., 2013. Papillomavirusassociated diseases. Vet Clin North Am Equine Pract, 29, 643-655.

30. Kanat Ö., Ataseven VS., Babaeski S., Derelli F., Kumaş C., Doğan F., Bilge Dağalp S., 2019. Equine and bovine papillomaviruses from Turkish brood horses: a molecular identification and immunohistochemical study. Vet Arhiv, 89, 601-611.

31. Borzacchiello G., 2007. Bovine papillomavirus infections in animals. Commun Curr Res Educ Top Trends Appl Microbiol,2, 673-679.

32. Altamura G., Jebara G., Cardeti G., Borzacchiello G., 2018. Felis catus papillomavirus type-2 but not type- 1 is detectable and transcriptionally active in the blood of healthy cats. Transbound Emerg Dis, 65, 497-503.

33. Dunowska M., Munday JS., Laurie RE., Hills SFK., 2014. Genomic characterisation of Felis catus papillomavirus 4, a novel papillomavirus detected in the oral cavity of a domestic cat. Virus Genes, 48, 111-119.

34. Munday JS., 2014. Papillomaviruses in felids. Vet J, 199, 340-347.

35. Munday JS., Thomson NA., Luff JA., 2017. Papillomaviruses in dogs and cats. Vet J, 225, 23-31.

36. Munday JS., Dittmer KE., Thomson NA., Hills SF., Laurie RE., 2017. Genomic characterisation of Felis catus papillomavirus type 5 with proposed classification within a new papillomavirus genus. Vet Microbiol, 207, 50-55.

37. Lange CE., Favrot C., 2011. Canine Papillomaviruses. Vet Clin North Am Small Anim Pract, 41, 1183-1195.

38. Günay C., Sağlıyan A., Özkaraca M., 2011. Bir köpekte oral papillomatozis ve cyclophosphamide ile sağaltımı. FÜ Sağ Bil Vet Derg, 25, 135-139.

39. Lange CE., Tobler K., Schraner EM., Vetsch E., Fischer NM., Ackermann M., Favrot C., 2013. Complete canine papillomavirus life cycle in pigmented lesions. Vet Microbiol, 162, 388-395.

40. Munday JS., Tucker RS., Kiupel M., Harvey CJ., 2015. Multiple oral carcinomas associated with a novel papillomavirus in a dog. J Vet Diagn Invest, 27, 221-225.

41. Dogan F., Dorttas SD., Dagalp SB., Ataseven VS., Alkan F., 2018. A teat papillomatosis case in a Damascus goat (Shami goat) in Hatay province, Turkey: a new putative papil-lomavirus? Arch Virol, 163, 1635-1642. 